\title{
Detection of Genes Related to Resistance to Silver Nanoparticles in Bacteria from Secondary Endodontic Infections
}

\author{
Marco Felipe Salas-Orozco ${ }^{(D},{ }^{1}$ Nereyda Niño Martínez $\left(\mathbb{D},{ }^{2}\right.$ \\ Gabriel-Alejandro Martínez-Castañón $\left(\mathbb{1},{ }^{2}\right.$ Fernando Torres Méndez, ${ }^{1}$ Nuria Patiño-Marín, ${ }^{1}$ \\ and Facundo Ruiz $\mathbb{( D}^{2}$ \\ ${ }^{1}$ Facultad de Estomatología, Universidad Autónoma de San Luis Potosí, San Luis Potosí, Mexico \\ ${ }^{2}$ Facultad de Ciencias, Universidad Autónoma de San Luis Potosí, San Luis Potosí, Mexico \\ Correspondence should be addressed to Nereyda Niño Martínez; nereyda.nino@uaslp.mx
}

Received 1 April 2019; Revised 19 July 2019; Accepted 20 August 2019; Published 12 September 2019

Academic Editor: Andrew R. Barron

Copyright (c) 2019 Marco Felipe Salas-Orozco et al. This is an open access article distributed under the Creative Commons Attribution License, which permits unrestricted use, distribution, and reproduction in any medium, provided the original work is properly cited.

\begin{abstract}
Introduction. Silver nanoparticles are used in endodontics due to their antimicrobial activity, although it is considered that bacteria are unable to develop resistance to silver nanoparticles. Silver resistance genes have been related to resistance to nanoparticles and antibiotics. The presence of these resistance genes has not been studied in endodontic bacteria. The objective of this study is to report the prevalence of silver resistance genes in endodontic bacteria. Methods. The selected teeth were isolated using a rubber dam and any restoration, post, or caries was eliminated. The operative field was disinfected, and the root-filling material was removed. The samples were obtained using three sterile paper points to absorb the fluid of the root canal. The DNA from the samples and the control organism was extracted, and the detection of the silCBA resistance genes was carried out by PCR. Results. The results of this study show a high prevalence $(73.3 \%)$ of silCBA silver resistance genes. The Spearman rank correlation coefficient was utilized to identify correlations between the presence of genes and clinical variables. Conclusions. This study reports a high frequency of silver resistance genes related to nanoparticle resistant from bacteria.
\end{abstract}

\section{Introduction}

Nanoparticles (NPs) have been widely used in various areas of dentistry, mainly due to their potent antibacterial property [1]. In endodontics, silver nanoparticles (AgNPs) are used to combat the presence of biofilms [2]. This is because AgNPs have several advantages compared to $\mathrm{NaOCl}$ (the gold standard of disinfection in endodontics). AgNPs can retain their antibacterial efficacy in the presence of dentine and have greater biocompatibility, especially at low concentrations [3].

In general, it is mentioned that silver nanoparticles exert their bactericidal action through two mechanisms. The first mechanism consists of the direct penetration of the nanoparticle $(<10 \mathrm{~nm})$ into the bacterial cell, and the second is the release of silver ions (by nanoparticles $>10 \mathrm{~nm}$ ) that can also enter the bacterial cells and react with their components causing the death of the bacteria. Although it is thought that bacteria are not capable of developing resistance to silver nanoparticles, this has not been well studied, although silver-resistant bacteria isolated from clinical and nonclinical environments have been reported $[4,5]$. The first clinical bacterium with silver resistance described was Salmonella typhimurium. The first plasmid coding for bacterial resistance to $\mathrm{Ag}+$ was isolated from this bacterium. The plasmid was named pMG101, and it confers resistance to $\mathrm{Ag}+, \mathrm{Hg}+$, and tellurite as well as antibiotics, such as ampicillin, chloramphenicol, tetracycline, and streptomycin. This plasmid contains a region of $14.2 \mathrm{~kb}$ (sil operon) with nine ORFs (open reading frames) arranged in three transcriptional units (silCFBAGP, silRS, and silE) expressed from a different promoter. These transcriptional subunits are collectively designated as the Sil operon [6]. The first transcriptional unit is composed of silCFBAGP. This transcription unit encodes an internal membrane protein complex formed by three 
subunits ( $s i l A$, silB, and silC). These three components form an efflux pump that is a member of the family of resistance, nodulation, and cell division (RND) transporters [7]. SilP is a member of the ATPase family of heavy metal resistance. SilG and silF are silver chaperones responsible for kidnapping the silver ions and transporting them to silP and silCBA complexes. In the second transcription unit and upstream of silE and in the same orientation of this, there is a gene pair, silRS, that encodes a transcriptional response regulatory protein and a membrane sensing kinase. The last transcriptional unit is composed of silE, which encodes a periplasmic protein that also binds to Ag+. Finally, between silA and silP and between silC and silB, there are two ORFs of 105 and 96aa, respectively, of unassigned function [8]. The efflux pumps synthesized from the expression of the aforementioned genes ( silCBA and silP) could participate as a mechanism of resistance to silver nanoparticles. This mechanism would work through the expulsion of silver ions, preventing them from affecting the internal components of the bacteria.

The endodontic bacteria of secondary infections present a high prevalence of plasmids that carry genes of resistance to antibiotics [9]. Recently, it was found that plasmids can also contain metal resistance genes [10]. This is due to a costimulation and coselection of resistance genes [11]. Therefore, the objective of this study was to identify the presence of silver resistance genes ( teeth. The detection of this type of genes has not been done before in bacteria from secondary endodontic infections. The presence of these genes in this type of resistant infections would lead to reevaluating the short- and long-term use of silver nanoparticles as antimicrobial agents in resistant infections like a secondary endodontic infection.

\section{Materials and Methods}

2.1. Bacterial Strain. The bacterial strain Enterobacter cloacae 13047 was acquired from the National Collection of Microbial Strains and Cell Cultures of CINVESTAV-IPN. This bacterial strain was used as a positive control for the detection of silCBA genes, according to what was reported in previous studies [12]. Enterobacter cloacae 13047 was inoculated in Brain Heart Infusion (BHI) agar plate (Sigma-Aldrich, St. Louis, MO, USA) using a sterile bail and incubated for $24 \mathrm{~h}$ at $37^{\circ} \mathrm{C}$. After the incubation period, an inoculum was taken and placed in an Eppendorf tube with $1 \mathrm{ml}$ of phosphate-buffered saline (PBS; Sigma-Aldrich, St. Louis, MO, USA) and frozen at $-4^{\circ} \mathrm{C}$ until further processed.

2.2. Patient Selection. All patient procedures were approved by the Ethics Committee of the Stomatology Faculty of the Autonomous University of San Luis Potosí, Mexico (CEIFE-027-018). Patients provided written informed consent before being recruited in the study. All 30 patients had an endodontically treated tooth requiring endodontic retreatment. The teeth included in the study had had previous endodontic treatment, sensitivity to percussion, pain on palpation, periapical lesion, or fistulous tract. These clinical characteristics were recorded. Patients who have received antibiotic treatment during the last 3 months or patients with teeth that present mobility and periodontal pockets were excluded. Teeth with root fracture or that could not be isolated were eliminated from the study.

2.3. Sampling Procedure. This was a descriptive crosssectional study with consecutive nonprobabilistic sampling. The study was conducted from March to November 2018. We evaluated 735 patients, of which 30 patients met the inclusion criteria. The selected teeth were isolated using a rubber dam and any restoration, post, or caries was eliminated. The operative field was disinfected using 30\% hydrogen peroxide followed by $5.25 \%$ sodium hypochlorite [13]. Subsequently, $10 \%$ sodium thiosulfate (LabChem Inc., Pittsburgh, PA) [14] was used to inactivate sodium hypochlorite. Root-filling material was removed using K-files, Gates Glidden drills, Hedstrom files, or rotary files with no solvent. The working length was determined with the use of an apex locator (Raypex 5; VDW, Munich, Germany), and transoperative radiographs were taken to ensure complete removal of the filling material. Sterile saline solution was used to remove any remaining filling material and moisten the root canal before sampling. The samples were obtained using three sterile paper points placed in the root canal for about $30 \mathrm{~s}$ to absorb the fluid of the root canal [15]. Samples from multiradicular teeth were taken from the widest root canal or from the one that presented some periradicular lesion or exudate. After sampling, the paper points were transferred to a $1.5 \mathrm{ml}$ tube with $1 \mathrm{ml}$ of phosphate-buffered saline (PBS; Sigma-Aldrich, St. Louis, MO, USA). All the samples were frozen at $-4^{\circ} \mathrm{C}$ until further processed. After taking the sample, each patient received the indicated root canal retreatment.

2.4. DNA Extraction. DNA was extracted from the sample of a control organism (Enterobacter cloacae 13047) and all clinical samples using the following total DNA extraction protocol. The samples were centrifuged and then the phosphate-buffered saline (PBS; Sigma-Aldrich, St. Louis, MO, USA) was decanted to then add $500 \mu \mathrm{l}$ of TES buffer (Sigma-Aldrich, St. Louis, MO, USA), $50 \mu \mathrm{l}$ of Proteinase K (Invitrogen, Paisley, UK), and $40 \mu \mathrm{l}$ of SDS $10 \%$. These reagents were incubated at $55^{\circ} \mathrm{C}$ for $3 \mathrm{~h}$ in a thermo-block for their activation. After the incubation, the suspension was centrifuged for $15 \mathrm{~min}$ at $13000 \mathrm{rpm}$, and the supernatant was transferred to a new $1.5 \mathrm{ml}$ vial. To the recovered supernatant, $578 \mu \mathrm{l}$ of isopropanol (SigmaAldrich, St. Louis, MO, USA) was added, and it was allowed to incubate overnight. After incubation with isopropanol, the pellet was washed with $70 \%$ ethanol and resuspended in $30 \mu \mathrm{l}$ of TE buffer.

2.5. PCR Primers and PCR Protocol. The PCR reactions for each of the samples and the positive control were prepared using $1 \mu \mathrm{l}$ of total template DNA, for a total of $25 \mu \mathrm{l}$ of reaction. In the negative control, $1 \mu \mathrm{l}$ of milliQ water was used as a template. The primers used for the detection of the silCBA genes were those reported by Woods et al. [5]. Primers were purchased from T4oligo Company (Guanajuato, Mexico). SilCBA gene primer sequences were as follows: silCBA forward 
cgggaaacgctgaaaaatta and silCBA reverse gtacgttcccagcaccagtt. PCRs were carried out using the following PCR protocol: denaturation temperature was $95^{\circ} \mathrm{C}$ for $3 \mathrm{~min}$ followed by 45 cycles consisting of an initial denaturation at $95^{\circ} \mathrm{C}$ for $40 \mathrm{~s}$; the alignment temperature was $56^{\circ} \mathrm{C}$ for $40 \mathrm{~s}$ and an extension temperature of $72^{\circ} \mathrm{C}$ for $40 \mathrm{~s}$. A final extension step was performed at $72^{\circ} \mathrm{C}$ for $10 \mathrm{~min}$. All the amplifications were performed in a C1000 Touch $^{\mathrm{TM}}$ Thermal Cycler (Bio-Rad, California, USA). The PCR products were separated by gel electrophoresis with a $2 \%$ agarose gel stained with $0.5 \mathrm{mg} / \mathrm{ml}$ ethidium bromide and TAE (Tris-acetate-EDTA) as running buffer. In each agarose gel, a 50 bp DNA ladder (Invitrogen, Paisley, UK) was loaded to define PCR fragment sizes together with the positive control, negative control, and the samples. The electrophoresis consisted of $1 \mathrm{~h}$ at $70 \mathrm{~V} / \mathrm{cm}$. The agarose gels were revealed in an ENDURO $^{\text {TM }}$ GDS Gel Documentation System (Labnet International).

2.6. Clinical Features. The data for clinical features and genes detected were entered into a spreadsheet and analyzed.

2.7. Statistical Analysis. Categorical variables were reported with frequencies and percentages, while continuous variables were reported with means and standard deviations (SD). Categorical variables were analyzed as absence $=0$ and presence $=1$ to calculate correlations. Shapiro-Wilk and Brown Forsythe tests were performed to determine the distribution of the variables. The Spearman rank correlation coefficient was utilized to identify all correlations. A $P<0.05$ was considered statistically significant. Data were analyzed using JMP ver. 9.0 (SAS Institute, Cary, NC, USA) and Stata ver. 11.0 (Stata Corp LP, College Station, TX, USA) statistical software.

\section{Results}

The mean age of the patients was 46.43 years (range, 11-76). There were more female patients $(21=70 \%)$ than male patients $(9=30 \%)$ (Table 1$)$. The teeth from which the samples were taken consisted of 2 incisors, 1canine, 4 premolars, and 23 molars. Of the molar teeth, 14 were mandibular, and 5 were maxillary. Of all the samples analyzed, $22(73.34 \%)$ samples were positive for the silCBA resistance genes. The samples that were negative for the resistance genes analyzed were $8(22.6 \%)$ (Table 2). Despite the difference between men and women, the frequency of silCBA genes in both groups was very similar, $76.1 \%$ for women and $77.77 \%$ for men. The positive samples with injury were 9 (40.9\%). The positive samples with symptomatology were 15 (68.1\%). The positive samples that presented lesion and symptomatology were 5 (22.72\%). Some DNA bands are barely visible on the agarose gels (Figure 1), suggesting that the genes are present at a relatively low copy number in some samples.

The absence/presence of silver resistance genes (absence $=0$ and presence $=1$ ) was correlated with periapical lesion (absence $=0$ and presence $=1$ ), symptomatology (absence $=0$ and presence $=1$ ), and type of tooth (anterior $=0$ and posterior $=1)$. A Rho $=0.08$ (periapical lesion), 0.20 (tooth), and 0.05 (symptomatology) with a
TABLE 1: Silver resistance gene (silCBA) detection in root-filled teeth by PCR. Results and patients' data.

\begin{tabular}{|c|c|c|c|c|c|c|}
\hline Patients & Sex & $\begin{array}{c}\text { Age } \\
(y)\end{array}$ & Lesion & Symptomatology & Tooth & Genes \\
\hline 1 & Female & 38 & Yes & Yes & 44 & Yes \\
\hline 2 & Female & 53 & Yes & No & 13 & Yes \\
\hline 3 & Male & 66 & No & Yes & 22 & No \\
\hline 4 & Female & 14 & No & No & 26 & No \\
\hline 5 & Male & 42 & No & No & 36 & Yes \\
\hline 6 & Female & 44 & No & No & 45 & No \\
\hline 7 & Female & 45 & Yes & Yes & 26 & Yes \\
\hline 8 & Male & 40 & Yes & Yes & 26 & No \\
\hline 9 & Female & 49 & Yes & Yes & 46 & Yes \\
\hline 10 & Female & 30 & Yes & No & 46 & Yes \\
\hline 11 & Female & 76 & No & No & 14 & No \\
\hline 12 & Male & 59 & No & Yes & 47 & Yes \\
\hline 13 & Female & 67 & No & Yes & 34 & Yes \\
\hline 14 & Male & 41 & Yes & Yes & 37 & No \\
\hline 15 & Female & 26 & Yes & No & 47 & Yes \\
\hline 16 & Female & 39 & Yes & Yes & 36 & No \\
\hline 17 & Female & 70 & Yes & Yes & 47 & No \\
\hline 18 & Male & 25 & No & Yes & 11 & Yes \\
\hline 19 & Male & 58 & No & Yes & 16 & Yes \\
\hline 20 & Female & 18 & Yes & Yes & 46 & Yes \\
\hline 21 & Female & 11 & Yes & Yes & 36 & Yes \\
\hline 22 & Female & 55 & No & Yes & 16 & Yes \\
\hline 23 & Female & 68 & No & Yes & 37 & Yes \\
\hline 24 & Male & 36 & No & No & 47 & Yes \\
\hline 25 & Female & 63 & No & Yes & 37 & Yes \\
\hline 26 & Female & 62 & No & Yes & 17 & Yes \\
\hline 27 & Female & 48 & No & Yes & 47 & Yes \\
\hline 28 & Male & 36 & No & No & 25 & Yes \\
\hline 29 & Female & 68 & No & Yes & 15 & Yes \\
\hline 30 & Female & 46 & Yes & No & 24 & Yes \\
\hline
\end{tabular}

$P>0.05$ was obtained. Considering the three variables, the highest correlation identified was between the presences of silver resistance genes with posterior teeth.

\section{Discussion}

The objective of this study was to identify the presence of silCBA genes in a bacterial pool from root-filled teeth. During the review of the literature, no studies similar to ours were found in endodontic bacteria. The results of this study show a high presence of silCBA silver resistance genes. Of all the samples analyzed, $73.3 \%$ of the samples were positive for the desired genes. This is the first time that silver resistance genes have been identified in bacteria from root-filled teeth. There is only one previous report in which it was possible to isolate two strains of silver-resistant Enterobacter cloacae from samples of extracted teeth. In that study, only the presence of the silE silver resistance gene was identified in the 
TABLe 2: Summary of reported frequencies.

\begin{tabular}{lc}
\hline Variables & Frequency (\%) \\
\hline Sex & $21(70)$ \\
Female & $9(30)$ \\
Male & \\
Type of tooth & $3(10)$ \\
Anterior & $27(90)$ \\
Posterior & \\
Resistance genes & $\mathbf{0 8}(\mathbf{2 6 . 6 6 )}$ \\
Absent & $\mathbf{2 2 ( 7 3 . 3 4 )}$ \\
Present & $10(33.33)$ \\
Symptomatology & $20(66.66)$ \\
Absent & \\
Present & $17(56.66)$ \\
Periapical lesion & $13(43.34)$ \\
Absent & Mean \pm standard deviation \\
Present & $46.43 \pm 17.42$ \\
&
\end{tabular}

genomic and plasmid DNA from the two strains of silverresistant Enterobacter cloacae. The gene, silE, only encodes for a silver ion transport protein and is not always present together with the other genes that constitute the sil operon. In our study, we analyzed the presence of silCBA genes, since these are the ones that encode for the silver ion efflux pump, which is the main mechanism of resistance [16]. We consider that the presence of the silCBA genes reported in this study is high in comparison with what was previously reported. For example, Davis et al. isolated 97 bacteria, of which only 2 were resistant to $\mathrm{AgNO}_{3}$. These two bacteria (Enterobacter cloacae Ag703 and Enterobacter cloacae Ag1157) were also positive for the presence of the silE genes that represents $2 \%$ of the total bacteria isolated [16]. Finley et al. analyzed the presence of the 8 genes of the sil operon in 859 bacterial strains isolated from patients at a tertiary care facility. They found that these genes were present in 32 isolates, representing $3.7 \%$ of the total samples [12]. Woods et al. reported the presence of sil genes in 6 of 172 (3.4\%) bacteria isolated from chronic wounds in humans and horses. Sütterlin et al. analyzed the presence of silver resistance genes (silE, silS, and silP) in 839 isolated bacterial strains over a period of 10 years. At least one of the three silver resistance genes analyzed was present in $176(21 \%)$ strains of the 839 strains analyzed [17]. In one study, we found a prevalence of sil genes similar to that reported by us. Andrade et al. analyzed the presence of silA in 27 Enterobacter cloacae Complex (EcC) and 8 Enterobacter aerogenes isolates. They found the silA gene in 21 of 27 (78\%) $\mathrm{EcC}$ isolates, while the silA gene was found only in a single E. cloacae isolate [18].

The difference of the aforementioned results to those of our study may be due to the fact that in the aforementioned studies a preselection of bacteria capable of growing on agar supplemented with $\mathrm{AgNO}_{3}$ was done [5]. This preselection of bacterial strains tended to reduce consider- ably the number of strains from which the detection of the resistance genes was carried out. Besides, it is possible that some bacteria have the resistance genes but do not express them in sufficient quantities to allow them to grow on agar supplemented with $\mathrm{AgNO}_{3}$. This could have caused its incorrect elimination of the total bacterial strains studied. These factors could be the cause of the extremely low prevalence reported in previous studies in comparison with the high prevalence reported in this study. Another difference between our study and the previous studies is that we did the detection of genes in mixed bacterial samples, whereas most of the previous reports made the detection of the genes from pure cultures of bacterial strains.

The high prevalence of the silCBA resistance genes in endodontic bacteria from root-filled teeth reported in this study may be due to the fact that these genes were previously reported in bacteria like Enterobacter cloacae, Enterococcus sp., Klebsiella oxytoca, Klebsiella pneumoniae, Proteus mirabilis, Pseudomonas aeruginosa, and Staphylococcus aureus [12]. Some of these bacteria have also been reported in teeth with persistent endodontic infections. For example, Murad et al. reported the presence of Enterococcus faecalis, Enterococcus faecium, Klebsiella pneumoniae, Enterobacter cloacae, and Staphylococcus aureus in different percentages using checkerboard DNA-DNA hybridization [19]. Sunde et al. detected Staphylococcus aureus in persistent periradicular lesions after root canal treatment [20]. Peciuliene et al. isolated Proteus mirabilis, Klebsiella pneumoniae, and E. faecalis from root-filled teeth with chronic apical periodontitis [21]. Although the genes of the sil operon are only expressed by gram-negative bacteria, some studies also report the presence of these genes in gram-positive bacteria [12]. This could be due to the fact that these genes move together with antibiotic resistance genes in plasmids that could be present in both types of bacteria. Although the genes of the sil operon cannot be expressed in gram-positive bacteria, its presence in this type of bacteria is of importance. Under stress conditions, these genes could be transmitted to bacterial strains with the ability to express them $[22,23]$ due to horizontal gene transfer, which is increased in biofilms that are the main form of bacterial growth in infected root canals with secondary endodontic infection $[24,25]$.

The presence of silver resistance genes in endodontic bacteria could be due to the fact that these genes move together with antibiotic resistance genes found in plasmids, and clinical strains of bacteria species associated with root canal infections (like Enterococcus faecalis) can carry a large variety of plasmids [9]. For example, Pal et al. analyzed the genomic sequence of plasmids from NCBI bacterial genome database. They reported that frequently in the same plasmid could be found genes of resistance to antibiotics and metals [26]. Even nonpathogenic bacteria such as E. coli have a large presence of plasmids with both types of resistance genes [10]. The finding of these genes in endodontic bacteria is important since the efflux pumps expressed by them have been linked to the development of resistance to nanoparticles and antibiotics; and to date, this type of resistance has not been studied in endodontic bacteria. For example, Jianhua et al. exposed Pseudomonas aeruginosa PAO1 to different 


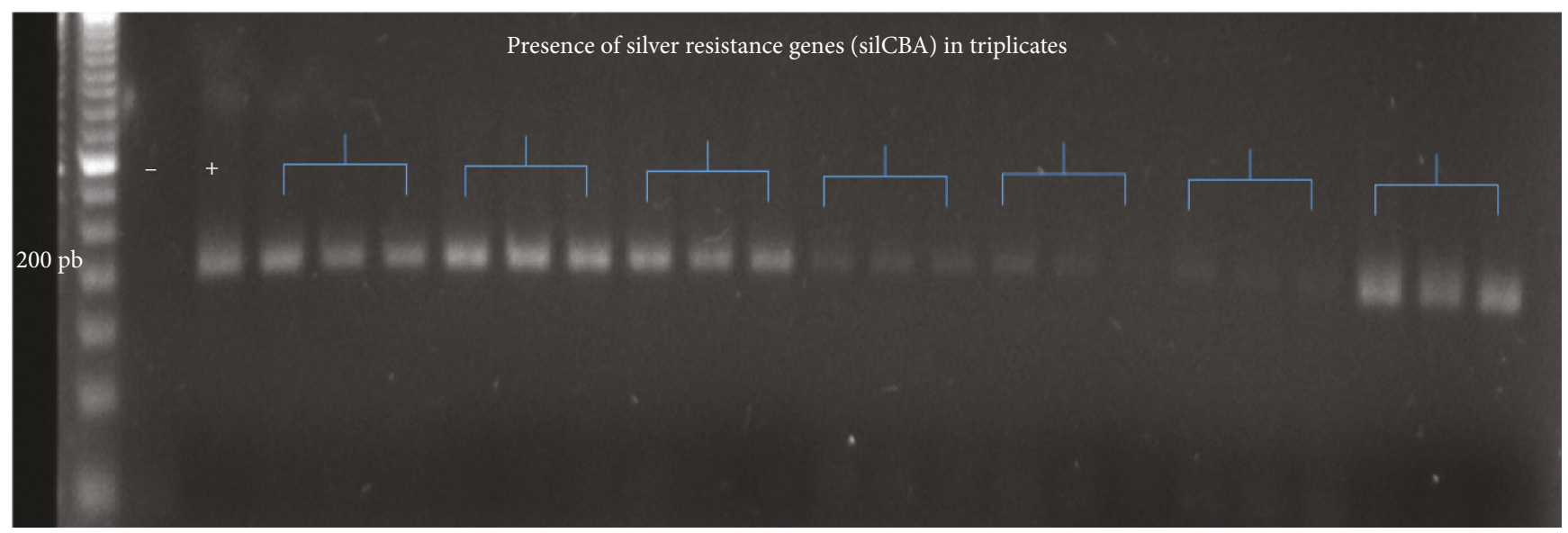

FIGURE 1: Agarose gel electrophoresis of PCR products from bacteria samples extracted from root-filled teeth. In the first well, the base pair marker (50 bp) was loaded. In the following wells, negative (milliQ water) and positive control (Enterobacter cloacae 13047) were loaded. The amplification products of each sample were loaded in triplicate from individual reactions.

concentrations $(1,10$, and $50 \mathrm{mg} / \mathrm{l} \mathrm{CuONPs})$ of copper nanoparticles. They found that this caused an upregulation of resistance genes that code for cation diffusion facilitator transporters, P-type ATPase efflux, and copper efflux pumps from the RND family [27]. Yang et al. also exposed Pseudomonas aeruginosa PAO1 to low concentration $(160 \mathrm{nM})$ of intact and weathered quantum dots (QDs) $(7.4 \pm 1.1 \mathrm{~nm})$. After the sublethal exposure to QDs, the transcriptomic analysis revealed an upregulation in the transcriptional unit $c z c \mathrm{ABC}$ that codes for three proteins $(C z c \mathrm{~A}, C z c \mathrm{~B}$, and $C z c \mathrm{C})$ that together form an efflux pump from the RND family. A secondary effect of the sublethal exposure was the increase of antibiotic resistance to different antibiotics (ampicillin, chloramphenicol, kanamycin, and tetracycline) reported by the increase in their minimum inhibitory concentrations (up to $100 \%$ in some cases) [28]. The resistance genes (silCBA) that we studied in this article also code for efflux pumps of the RND family (silCBA). In addition, the sil operon contains the gene silP that codes for an efflux pump of the ATPase family, although this efflux pump has not been well characterized [29]. There are reports in which negative and positive gram bacteria generate resistance to silver nanoparticles after exposure to sublethal doses, but none of these studies evaluates the participation of the silver resistance genes that code for efflux pumps from the RND family [30, 31]. For example, Kaweeteerawat et al. exposed gramnegative (E. coli) and gram-positive bacteria (S. aureus) at sublethal doses of silver nanoparticles and observed an increase in the minimum inhibitory concentrations after only four rounds of subculturing. The authors of this article did not investigate the participation of silver ion efflux pumps from the RND family in this type of resistance [32]. Mishra et al. treated Enterobacter cloacae 13047 and multidrug resistance Enterobacter cloacae, with a sublethal concentration of AgNPs $(6 \mathrm{mg} / \mathrm{ml})$ and silver-metal-carbohydrate nanoparticle (Ag-MCNPs) $(0.75 \mathrm{mg} / \mathrm{ml})$ for $0,30,60,120$, and $180 \mathrm{~min}$. They did not find a significant increase in the expression of the AcrAB-TolC efflux pump. In this study, the authors did not analyze the participation of silver ion efflux pumps in the development of resistance. The authors only analyzed the participation of the AcrAB-TolC efflux pump, which does not participate in the efflux of silver ions. The AcrAB-TolC efflux pump only participates in the expulsion of antibacterial drugs [33].

Recently, it has been hypothesized that the presence of this type of genes in bacteria is due not only to the presence of metals in the environment, but they are the result of the development of defenses against bacteria predatory organisms as the protozoa or as defense against immune system cells like macrophages. For example, both protozoa and macrophages employ $\mathrm{Zn}^{2+}$ and $\mathrm{Cu}^{+}$to attack Fe-S clusters (essential for bacterial survival) during phagocytosis of bacteria. Therefore, resistance to silver can be a by-product of copper and zinc resistance developed by bacteria to survive phagocytosis by protozoa and macrophages. This hypothesis is because most of the so-called sil determinants are part of a bigger genomic island (recently named "copper pathogenicity island") which confers resistance to copper and silver [34].

After a review of the literature, as far as we know, there are no studies in the endodontic literature in which the presence of resistance genes is correlated with the different clinical symptoms of resistant infections (secondary endodontic infection). Many studies have only focused on detecting the presence of resistance genes in different oral environments, including bacteria isolated from different types of endodontic infections $[35,36]$. Other studies have only been dedicated to associate the presence of certain bacterial species with the presence of clinical symptoms [37]. The only study similar to ours that we found during the review of the literature is that of De Lima et al. In this study, the authors only analyzed the association between the presence of lactamic resistance genes (blaTEM) and clinical parameters (pulpal diagnosis, sinus tract, pain, and swelling); but they found no association between these variables [38]. The correlation of the presence of resistance genes with the clinical symptoms of secondary endodontic infection could provide information on why certain bacteria are present in certain types of infection and how they influence their symptomatology. In our study, 
considering the three variables, the highest correlation identified was between the presences of silver resistance genes with posterior teeth. This is because this type of teeth is the first to be present in the oral cavity and therefore is the first to develop deep caries and present endodontic infection. In addition, the internal anatomy of this type of teeth is more complex, so they tend to have a greater diversity of microorganisms [39].

\section{Conclusion}

This study demonstrates a high prevalence of silver resistance genes in endodontic bacteria. This could indicate that endodontic bacteria are able to develop resistance to silver nanoparticles in the long term. This also invites us to reevaluate the use of nanoparticles (especially silver nanoparticles) as antimicrobial agents in endodontics, since the increase in this type of resistance could bring serious side effects such as costimulation of the increase in resistance to antibiotics and other antimicrobial agents, which would make the management of resistant infections (like secondary endodontic infections) even more difficult.

5.1. Future Perspectives. Despite the great variety of studies evaluating the antimicrobial capacity of nanoparticles, few studies have been devoted to studying the defense mechanisms of bacteria against nanoparticles. The authors of this paper call into action the need for better understanding of the long-term interactions between nanoparticles and microbes. It is important to determine all possible mechanisms of bacterial resistance not only to silver nanoparticles but also to the wide variety of metal and metal oxide nanoparticles. More studies are needed to determine which bacteria have nanoparticle resistance mechanisms, which is the capacity of bacteria to maintain the mechanisms of resistance and to transmit them to other species, and how the management of resistant infections could be affected by such resistance mechanism. This will help us to avoid in the future the appearance of this type of resistance and its possible side effects, which, as already mentioned, may be the costimulation of resistance to antibiotics and other antimicrobial agents, which is already a serious global health problem.

\section{Data Availability}

The data used to support the findings of this study are included within the article.

\section{Conflicts of Interest}

The authors deny any conflicts of interest.

\section{Acknowledgments}

This article was supported by Nanomateriales Multifuncionales para la Sustentabilidad y el Bienestar de la Sociedad (511-6/18-11856) (PROFIDES), FAI (C19-FAI-05-67.67), and CONACYT Scholarship number 460066.

\section{References}

[1] M. L. Cohen, "Nanotubes, nanoscience, and nanotechnology," Materials Science and Engineering: C, vol. 15, no. 1-2, pp. 1-11, 2001.

[2] M. Samiei, A. Farjami, S. M. Dizaj, and F. Lotfipour, "Nanoparticles for antimicrobial purposes in endodontics: a systematic review of in vitro studies," Materials Science and Engineering: C, vol. 58, pp. 1269-1278, 2016.

[3] J. E. Gomes-Filho, F. O. Silva, S. Watanabe et al., "Tissue reaction to silver nanoparticles dispersion as an alternative irrigating solution," Journal of Endodontia, vol. 36, no. 10, pp. 1698-1702, 2010.

[4] S. Vasileiadis, E. Puglisi, M. Trevisan et al., "Changes in soil bacterial communities and diversity in response to long-term silver exposure," FEMS Microbiology Ecology, vol. 91, no. 10, 2015.

[5] E. J. Woods, C. A. Cochrane, and S. L. Percival, "Prevalence of silver resistance genes in bacteria isolated from human and horse wounds," Veterinary Microbiology, vol. 138, no. 3-4, pp. 325-329, 2009.

[6] A. Gupta, K. Matsui, J.-F. Lo, and S. Silver, "Molecular basis for resistance to silver cations in Salmonella," Nature Medicine, vol. 5, no. 2, pp. 183-188, 1999.

[7] M. H. Saier, R. Tam, A. Reizer, and J. Reizer, "Two novel families of bacterial membrane proteins concerned with nodulation, cell division and transport," Molecular Microbiology, vol. 11, no. 5, pp. 841-847, 1994.

[8] C. P. Randall, A. Gupta, N. Jackson, D. Busse, and A. J. O'Neill, "Silver resistance in Gram-negative bacteria: a dissection of endogenous and exogenous mechanisms," Journal of Antimicrobial Chemotherapy, vol. 70, no. 4, pp. 1037-1046, 2015.

[9] C. Sedgley and D. B. Clewell, "Bacterial plasmids in the oral and endodontic microflora," Endodontic Topics, vol. 9, no. 1, pp. 37-51, 2004.

[10] L. Fang, X. Li, L. Li et al., "Co-spread of metal and antibiotic resistance within ST3-IncHI2 plasmids from E. coli isolates of food-producing animals," Scientific Reports, vol. 6, no. 1, 2016.

[11] C. Pal, K. Asiani, S. Arya et al., "Metal resistance and its association with antibiotic resistance," in Microbiology of Metal Ions, pp. 261-313, Elsevier, 2017.

[12] P. J. Finley, R. Norton, C. Austin, A. Mitchell, S. Zank, and P. Durham, "Unprecedented silver-resistance in clinically isolated Enterobacteriaceae: major implications for burn and wound management," Antimicrobial Agents and Chemotherapy, vol. 59, no. 8, pp. 4734-4741, 2015.

[13] A. Al-Ahmad, H. Ameen, K. Pelz et al., "Antibiotic resistance and capacity for biofilm formation of different bacteria isolated from endodontic infections associated with root-filled teeth," Journal of Endodontics, vol. 40, no. 2, pp. 223-230, 2014.

[14] J. Cook, R. Nandakumar, and A. F. Fouad, "Molecular-and culture-based comparison of the effects of antimicrobial agents on bacterial survival in infected dentinal tubules," Journal of Endodontics, vol. 33, no. 6, pp. 690-692, 2007.

[15] I. Rocas, I. Jung, C. Lee, and J. Siqueirajr, "Polymerase chain reaction identification of microorganisms in previously rootfilled teeth in a South Korean population," Journal of Endodontics, vol. 30, no. 7, pp. 504-508, 2004.

[16] I. J. Davis, H. Richards, and P. Mullany, "Isolation of silverand antibiotic-resistant Enterobacter cloacae from teeth," Molecular Oral Microbiology, vol. 20, no. 3, pp. 191-194, 2005. 
[17] S. Sütterlin, M. Dahlö, C. Tellgren-Roth, W. Schaal, and Å. Melhus, "High frequency of silver resistance genes in invasive isolates of Enterobacter and Klebsiella species," Journal of Hospital Infection, vol. 96, no. 3, pp. 256-261, 2017.

[18] L. N. Andrade, T. E. S. Siqueira, R. Martinez, and A. L. C. Darini, "Multidrug-resistant CTX-M- $(15,9,2)$-and KPC-2producing Enterobacter hormaechei and Enterobacter asburiae isolates possessed a set of acquired heavy metal tolerance genes including a chromosomal sil operon (for acquired silver resistance)," Frontiers in Microbiology, vol. 9, 2018.

[19] C. F. Murad, L. M. Sassone, M. Faveri, R. Hirata Jr., L. Figueiredo, and M. Feres, "Microbial diversity in persistent root canal infections investigated by checkerboard DNADNA hybridization," Journal of Endodontics, vol. 40, no. 7, pp. 899-906, 2014.

[20] P. Sunde, I. Olsen, G. Debelian, and L. Tronstad, "Microbiota of periapical lesions refractory to endodontic therapy," Journal of Endodontics, vol. 28, no. 4, pp. 304-310, 2002.

[21] V. Peciuliene, A. H. Reynaud, I. Balciuniene, and M. Haapasalo, "Isolation of yeasts and enteric bacteria in root-filled teeth with chronic apical periodontitis," International Endodontic Journal, vol. 34, no. 6, pp. 429-434, 2001.

[22] K. L. Wyres and K. E. Holt, "Klebsiella pneumoniae as a key trafficker of drug resistance genes from environmental to clinically important bacteria," Current Opinion in Microbiology, vol. 45, pp. 131-139, 2018.

[23] K. L. Palmer, V. N. Kos, and M. S. Gilmore, "Horizontal gene transfer and the genomics of enterococcal antibiotic resistance," Current Opinion in Microbiology, vol. 13, no. 5, pp. 632-639, 2010.

[24] J. S. Madsen, M. Burmølle, L. H. Hansen, and S. J. Sørensen, "The interconnection between biofilm formation and horizontal gene transfer," FEMS Immunology \& Medical Microbiology, vol. 65, no. 2, pp. 183-195, 2012.

[25] G. Svensäter and G. Bergenholtz, "Biofilms in endodontic infections," Endodontic Topics, vol. 9, no. 1, pp. 27-36, 2004.

[26] C. Pal, J. Bengtsson-Palme, E. Kristiansson, and D. G. J. Larsson, "Co-occurrence of resistance genes to antibiotics, biocides and metals reveals novel insights into their co-selection potential," BMC Genomics, vol. 16, no. 1, 2015.

[27] J. Guo, S. H. Gao, J. Lu, P. L. Bond, W. Verstraete, and Z. Yuan, "Copper oxide nanoparticles induce lysogenic bacteriophage and metal-resistance genes in Pseudomonas aeruginosa PAO1," ACS Applied Materials \& Interfaces, vol. 9, no. 27, pp. 22298-22307, 2017.

[28] Y. Yang, J. M. Mathieu, S. Chattopadhyay et al., "Defense mechanisms of Pseudomonas aeruginosa PAO1 against quantum dots and their released heavy metals," ACS Nano, vol. 6, no. 7, pp. 6091-6098, 2012.

[29] M. Blanco Massani, J. Klumpp, M. Widmer et al., "Chromosomal Sil system contributes to silver resistance in E. coli ATCC 8739," Biometals, vol. 31, no. 6, pp. 1101-1114, 2018.

[30] A. Panáček, L. Kvítek, M. Smékalová et al., "Bacterial resistance to silver nanoparticles and how to overcome it," Nature Nanotechnology, vol. 13, no. 1, pp. 65-71, 2018.

[31] J. L. Graves, M. Tajkarimi, Q. Cunningham et al., "Rapid evolution of silver nanoparticle resistance in Escherichia coli," Frontiers in Genetics, vol. 6, 2015.

[32] C. Kaweeteerawat, P. Na Ubol, S. Sangmuang, S. Aueviriyavit, and R. Maniratanachote, "Mechanisms of antibiotic resistance in bacteria mediated by silver nanoparticles," Journal of Toxi- cology and Environmental Health, Part A, vol. 80, no. 23-24, pp. 1276-1289, 2017.

[33] M. Mishra, S. Kumar, R. K. Majhi, L. Goswami, C. Goswami, and H. Mohapatra, "Antibacterial efficacy of polysaccharide capped silver nanoparticles is not compromised by AcrABTolC efflux pump," Frontiers in Microbiology, vol. 9, 2018.

[34] X. Hao, F. L. Lüthje, Y. Qin et al., "Survival in amoeba-a major selection pressure on the presence of bacterial copper and zinc resistance determinants? Identification of a "copper pathogenicity island"," Applied Microbiology and Biotechnology, vol. 99, no. 14, pp. 5817-5824, 2015.

[35] P. M. Lang, R. C. Jacinto, T. S. Dal Pizzol, M. B. C. Ferreira, and F. Montagner, "Resistance profiles to antimicrobial agents in bacteria isolated from acute endodontic infections: systematic review and meta-analysis," International Journal of Antimicrobial Agents, vol. 48, no. 5, pp. 467-474, 2016.

[36] L. C. Moraes, M. V. R. Só, T. S. Dal Pizzol, M. B. C. Ferreira, and F. Montagner, "Distribution of genes related to antimicrobial resistance in different oral environments: a systematic review," Journal of Endodontia, vol. 41, no. 4, pp. 434-441, 2015.

[37] N. Zargar, M. A. Marashi, H. Ashraf, R. Hakopian, and P. Beigi, "Identification of microorganisms in persistent/secondary endodontic infections with respect to clinical and radiographic findings: bacterial culture and molecular detection," Iranian Journal of Microbiology, vol. 11, no. 2, pp. 120-128, 2019.

[38] B. R. de Lima, G. F. Nicoloso, C. C. Fatturi-Parolo, M. B. C. Ferreira, F. Montagner, and L. Casagrande, "Prevotella strains and lactamic resistance gene distribution in different oral environments of children with pulp necrosis," International Endodontic Journal, vol. 51, no. 11, pp. 1196-1204, 2018.

[39] I. Prada, P. Mico-Munoz, T. Giner-Lluesma, P. Mico-Martinez, N. Collado-Castellano, and A. Manzano-Saiz, "Influence of microbiology on endodontic failure. Literature review," Medicina Oral Patología Oral y Cirugia Bucal, vol. 24, no. 3, pp. e364-e372, 2019. 


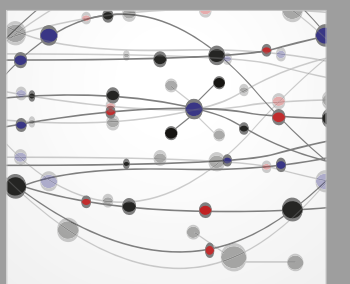

The Scientific World Journal
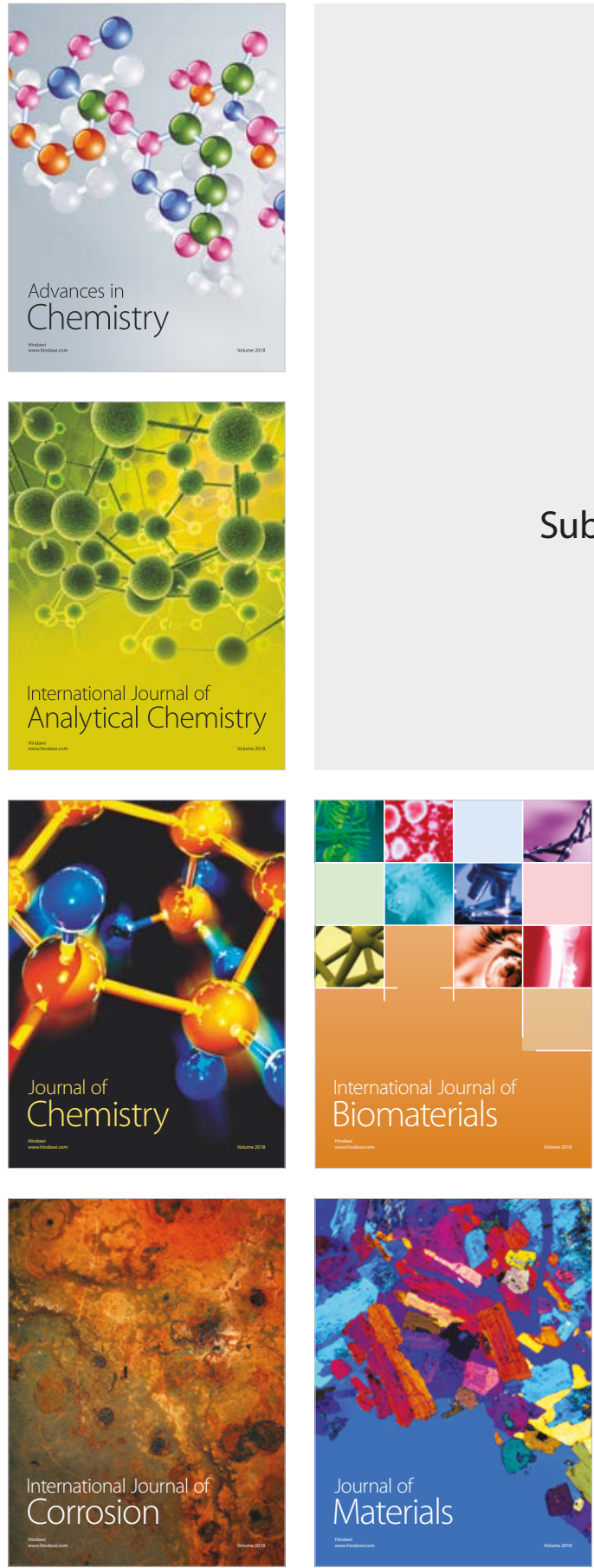

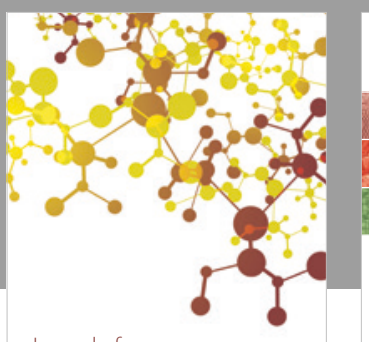

Journal of

Applied Chemistry
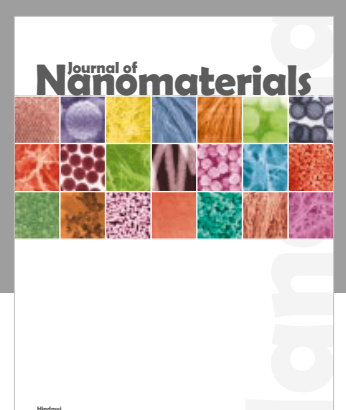

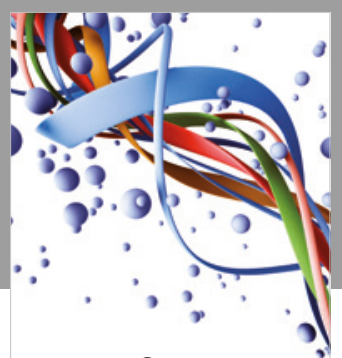

Scientifica

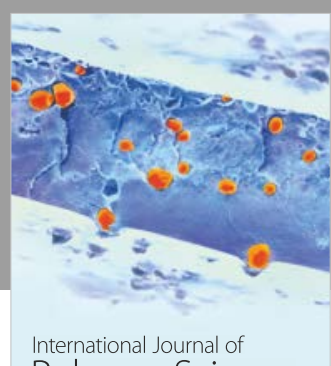

Polymer Science

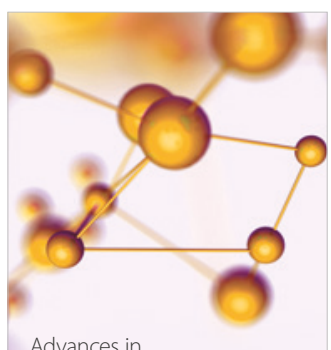

Physical Chemistry
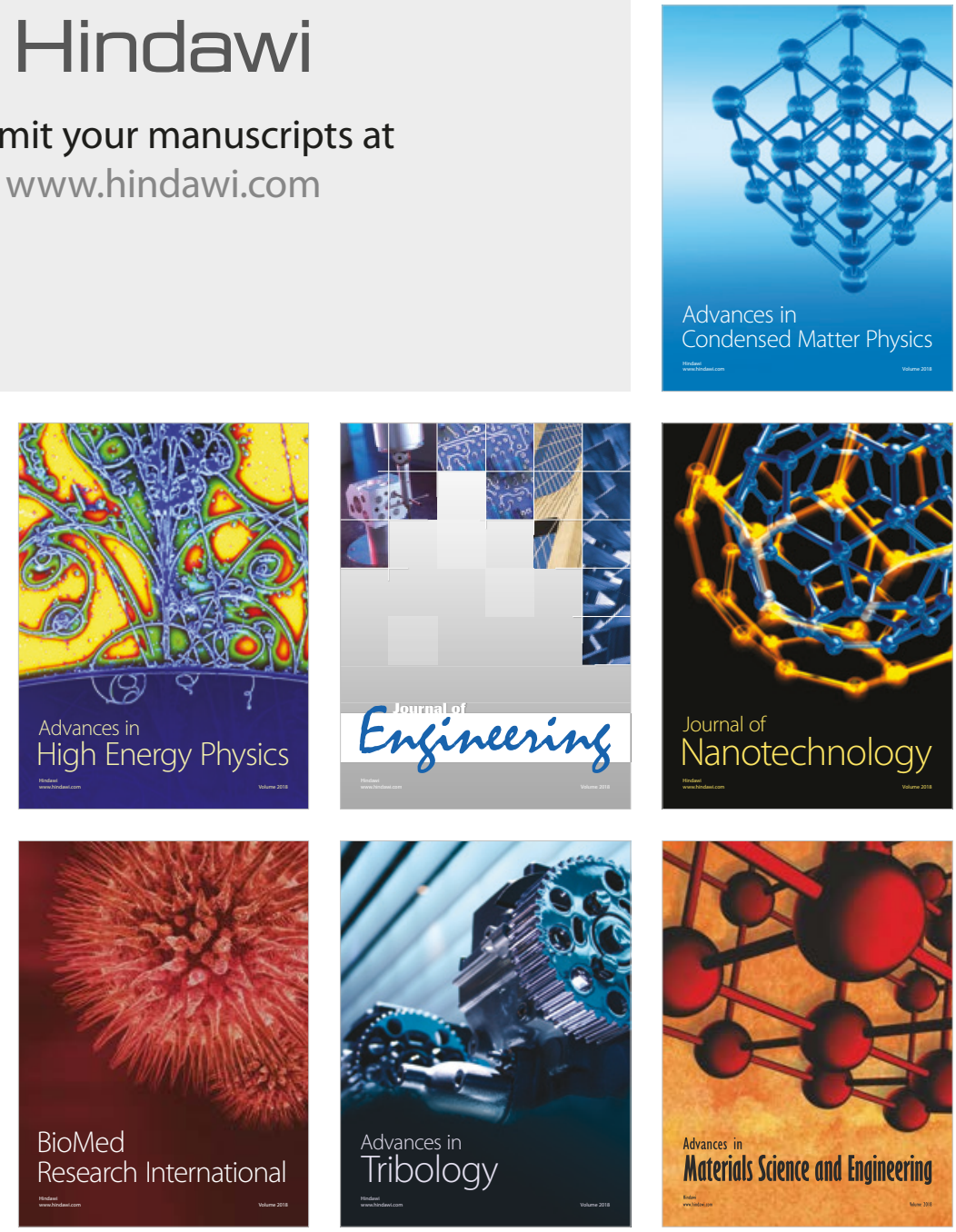